\title{
Resource Publicness Matters in Organizational
}

\section{Perceptions $^{\dagger}$}

\author{
Chengxin $\mathrm{Xu}^{1}$ and Huafang $\mathrm{Li}^{2}$ \\ ${ }^{1}$ Seattle University \\ ${ }^{2}$ Grand Valley State University
}

(Chengxin Xu \& Huafang Li, 2021. Resource Publicness Matters in Organizational

Perceptions. Public Administration Review, DOI: 10.1111/puar.13369)

\begin{abstract}
Publicness theory deepens our understanding of differences and similarities of organizational behavior. However, in areas in which public, nonprofit, and private organizations compete to serve people, it remains unclear how the level of dimensional publicness influences individuals' perceptions and choices of organizations. In this study, we present evidence from two online experiments examining the way people's perceptions of resource publicness (operationalized as government funding, donations, and service fees) of elderly care centers in the U.S. influence their judgment of organizations and service choices. Findings suggest that people perceive donative organizations to be the warmest and most competent, followed by government-funded and commercial organizations. We conclude that individuals' perceptions of resource publicness lead to different judgment that may influence their service choice decisions.
\end{abstract}

\footnotetext{
${ }^{\dagger}$ Chengxin Xu, Assistant Professor, Seattle University. Email: cxu1@seattleu.edu; Huafang Li, Assistant Professor, Grand Valley State University, Email: lih@gvsu.edu. This research is supported by the Center for Experimental and Behavioral Public Administration (CEBPA) at the School of Public Affairs and Administration, Rutgers University-Newark. We thank insightful comments from Sebastian Jilke, Lindsey McDougle, Jiahuan Lu, Danbee Lee, Ivan P. Lee, and participants at the Annual Conference of the Association for Research on Nonprofit Organizations and Voluntary Action.
} 
Theories of publicness were developed to answer one of the most essential questions in public organization studies: In what ways do public and private organizations differ? Since the 1970s, scholars' mounting efforts in building theory and conducting empirical examinations have made the answer to this question increasingly comprehensive (Andrews, Boyne and Walker 2011; Bozeman and Bretschneider 1994; Bozeman and Moulton 2011; Rainey 1979). While the traditional ownership model of publicness implies that public organizations behave differently as a consequence of their legal status (publicly vs. privately owned), the dimensional model theorizes that the levels of publicness in other of the organization's dimensions, including the funding source and political control, will lead to significantly different organizational outcomes (Bozeman 1987). An early comparison between the two models showed that both theories of publicness help explain organizational performance variations (Bozeman and Bretschneider 1994). The comparison results implied that, given any ownership status of the organization, strategically managing dimensional factors can harness the benefits of publicness.

However, the publicness theory has not yet been developed fully for people to understand the role of publicness in organization management and policy implementation. In particular, to date, our knowledge about the behavioral implication of institutional publicness has been fruitful but insufficient. Most empirical studies of publicness theory focus on ownership publicness (Andrews, Boyne and Walker 2011; Hvidman and Andersen 2015; Marvel 2016; Meier, Johnson and An 2019). However, experimental examinations of the relation between publicness and people's judgments of the organization largely ignored the dimensional publicness, which captures more nuanced variations across organizations with the same legal status. With the increasing demand for accountability via transparency, dimensional publicness that used to be in the black box now has the potential to influence the public in more direct ways than before. In a competitive market of social service delivery, probing the behavioral implication of organizational publicness from a dimensional perspective will provide practitioners with more feasible insights about managing organizations and 
serving clients. For example, citizens' reaction may vary across organizations with different major revenues. As such, public organizations need to communicate strategically with citizens to encourage effective coproduction (Li 2020). Effective communications can also help avoid congestion and unequal delivery of social service by reducing systematic bias against certain types of organizations.

In this study, we advance the publicness theory by extending the discussion of dimensional publicness and experimentally testing the relation between resource publicness and public perceptions of social service organizations (SSOs). In particular, we investigated the way the general public reacts to various levels of organizational resource publicness. Financial resources are a fundamental component that influences organizational strategies and practices, and financial information is one of the most important types of information that influences the public's reaction (Li 2020; Li and McDougle 2017). As major coordinators or contractors of public services, SSOs in the U.S. have three major revenue sources - service fees, donations, and government funding — which represent three different levels of resource publicness (Bozeman 1987). We propose that people will judge a SSO based on its resource publicness by using their prototypical understanding of the revenue source. Previous theories suggest that the level resource publicness influences organizational behavior and image through mechanisms within organizations, such as the level of responsiveness and enforced controls (Andrews, Boyne and Walker 2011). In contrast, the public outside the organization may simplify the resource information and form a quick impression of the organization and then react accordingly.

We conducted two online experiments to demonstrate the way resource publicness influences people's perception of a hypothetical elderly care center, a typical SSO in the U.S., and their subsequent service choices. This study focuses on two psychological traitsperceived warmth and competence - to capture people's perceptual reactions to the focal organization's resource publicness. As components of stereotypical content (Fiske, Cuddy and Glick 2007), warmth and competence not only help us link the organizational image to 
people's behavior, but also provide practical implications for public and nonprofit managers to design more specific strategies to enhance their organizational reputation and legitimacy. In Study 1, we showed that, ceteris paribus, people's perceived warmth and competence of SSOs varied according to the levels of resource publicness measured by their major revenues. In Study 2, we confirmed the findings of Study 1 and demonstrated that SSOs' instrumental or prosocial missions moderate resource publicness' effects on people's perceived competence. Using these two online experiments, we provided causal evidence of the effect of the organization's resource publicness on people's perceptions of the organization.

The paper proceeds as follows. After reviewing the literature on sector differences, ownership, and resource publicness, we propose a set of hypotheses to test experimentally. We then present two experiments and their results. The paper concludes with a discussion of the studies' theoretical and practical contributions and their limitations.

\section{Theory}

\section{Publicness and Sector Differences}

The publicness theory was developed to explain sector differences (Bozeman 1987; Bozeman and Bretschneider 1994). Moving from traditional theoretical guidelines which political economy approaches provide, Bozeman (1987) proposed a model to address the publicness puzzle and explain the public-private difference from an organizational perspective. Theoretically, one organization's publicness determines its managerial practices, including strategic planning, hiring, budgeting, and other related organizational behavior, and it is argued that the level of publicness influences organizational performance. Following Bozeman's (1987) dimensional framework, scholars have provided considerable evidence that shows that the performance of public and private organizations with similar social missions differs. Building on the dimensional publicness model, Moulton (2009) and Bozeman and Moulton (2011) extended the publicness framework by integrating empirical publicness and 
normative publicness, which provides a more systematic theoretical foundation to explore the relation between various levels of publicness and the achievement of public value.

\section{Resource Publicness}

Publicness theory contains both ownership and dimensional perspectives (Bozeman and Bretschneider 1994; Bozeman and Moulton 2011). The ownership publicness assumes that different organizations' ownership (public vs. private) leads to various management practices, such as goal setting, the budgetary process, strategic decision making, organizational culture, etc. Collectively, these differences contribute to observable differences in organizational behavior (e.g. Brewer and Brewer Jr. 2011; Jilke, van Dooren and Rys 2018). Meanwhile, ownership publicness affects organizations' internal management and the way citizens judge their social service delivery performance (e.g. Andrews, Boyne and Walker 2011; Hvidman and Andersen 2015). However, other empirical comparisons between public, nonprofit, and private organizations have demonstrated mixed findings of the relation between an organization's legal ownership and its performance and organizational perceptions (Amirkhanyan, Kim and Lambright 2008; Meier and An 2020). Such inconsistencies imply that other factors, particularly institutional elements that organizations with different legal status share, may shape the organizational practice in the same way, and lead to insignificant differences among organizations (Miller and Moulton 2014).

The dimensional publicness theory supplements the ownership publicness theory. In Bozeman's dimensional model, resource publicness is suggested to be one of the key elements that shapes the focal organization's level of publicness, which, in turn, determines its management practices and performance (Bozeman 1987). Thus, resource publicness influences the focal organization in both its organizational motivation and external control. Organizations with a higher level of resource publicness are less motivated to maximize their profits and efficiency and less responsive to the public who receives the services; instead, they are more responsive to external controlling forces, such as politicians and governmental sponsors 
(Niskanen 1971). Weisbrod (1997) pointed out that the revenue source determines organizational incentives, which influence organizational behavior further, including the composition of labor and the production and delivery of types of goods and services. In addition, organizations may be subject to external controls and therefore, act under the pressure of resource dependence. For example, nonprofit organizations that tend to have government funding have stronger incentives to adjust managerial practices, including being oriented more bureaucratically and building stronger domain consensus with the government (Lu 2015).

The traditional public-private dichotomous approach does not sufficiently capture the role of donations, which have a unique function in financing public services. Donations represent a peculiar level of publicness, as they are generated neither by commercial exchange nor by law enforcement. Therefore, donations affect SSOs' operation and performance in ways that are different from government funding and commercial revenues. Donations, particularly unrestricted contributions, may ease the focal organization's pressure to generate revenue and allow it to focus on its core mission to deliver services. Thus, organizations with major revenues from donations have fewer motivations to maximize profits (Hansmann 1980), while those with more government-funded resources are less responsive to the public and more likely to yield to governmental control (O'Regan and Oster 2002). In addition, public donors and beneficiaries hold donor-funded organizations directly accountable (Saxton, Neely and Guo 2014). They do so by monitoring whether they achieve the public values stated in their missions and whether the traditional public-private dichotomous approach generates sustainable donations.

\section{Perceptual Judgment: Stereotype Content Model}

People's perceptions of the focal organization affect whether they will support it. For example, people's positive perceptions of a nonprofit, such as perceived trustworthiness and efficacy, increase purchases of charitable goods and services (Hansmann 1980), charitable 
giving (Bekkers 2003), and volunteerism (Handy et al. 2010). Individuals' perceptions of an organization are also fundamental in establishing organizational legitimacy (Suddaby, Bitektine and Haack 2017). Thus, scholars study factors that alter people's perceptions of SSOs to provide managers and policymakers evidence-based strategies that will help improve organizational and policy outcomes.

Sociological and psychological research has suggested two fundamental dimensions warmth (e.g., kindness, generosity, etc.) and competence (e.g., effectiveness, efficiency, etc.) - that influence perceptions (Abele and Wojciszke 2007). Scholars have developed this twodimensional approach further into the stereotype content model (SCM) (Cuddy, Glick and Beninger 2011; Fiske 2018). These psychological traits lead ultimately to people's different emotional and behavioral reactions to their perceptual judgments of individuals (Todorov et al. 2005), social groups (Cuddy, Fiske and Glick 2007), and organizations (Aaker, Vohs and Mogilner 2010; Lee, Bolton and Winterich 2017; Seemann et al. 2014).

Combinations of different levels of warmth and competence help scholars capture people's emotional and behavioral reactions to an organization more accurately. Experimental studies on organizational stereotypes have found that people are more likely to purchase from an organization that is perceived to be competent, and less likely to interact, including purchasing and charitable giving, with an organization that they perceive is less warm (Aaker, Vohs and Mogilner 2010; Lee, Bolton and Winterich 2017). In addition, compared to previous measurements of public perception, the SCM provides more constructive implications for practitioners. For example, corporate social responsibility (CSR) strategies help private firms increase perceived warmth that leads to more sales (Chernev 2015). According to institutional theory, perceived warmth and competence are related to moral legitimacy and pragmatic legitimacy, respectively (Deephouse and Suchman 2008). Therefore, variations in warmth and competence may help scholars predict the focal organization's legitimacy, which is an outcome of collective perceptual judgments (Suddaby, Bitektine and Haack 2017). Nuances of perceived warmth and competence will help organizational managers diagnose 
problematic practices and create more specific strategies to generate resources and manage legitimacy. Hence, using the SCM to measure people's perceptions of organizations has practical implications for managing performance (Cuddy, Glick and Beninger 2011).

\section{Hypotheses}

\section{Perceptual Differences in Resource Publicness}

To facilitate our discussion, we defined organizations that rely principally on donations, fees for services, and governmental funding as donative, commercial, and governmentfunded organizations, respectively. We argue that people perceive SSOs with various levels of resource publicness differently because of their stereotypical understanding of sector differences. Similar to other kinds of stereotypes, sector stereotypes originate from people's psychological reactions in nature to one sector's values and practice or widely accepted opinions of characteristics that represent the sector mostly (Bordalo et al. 2016; Williams, Sng and Neuberg 2016). To establish hypotheses, we use the donative organization as the reference group, as most of early SSOs rely on donation as the major revenue source (Salamon 1993), and map the perceptual differences on SCM, warmth and competence. Notice that our discussion of perceptual difference is limited to social service markets in which nonprofit, for-profit, and government organizations coexist and compete. It is important to raise this limitation because people's perceptions of organizations may vary across types of services the organization provides (DiMaggio and Anheier 1990).

First, we propose that a government-funded organization will be perceived to be less warm than a donative organization because citizens distrust government. Declining trust in the public sector is a common phenomenon worldwide. The 2016 Edelman Trust Barometer indicated that the government is perceived to have the lowest level of trustworthiness among other institutions, including NGOs, businesses, and the media (Kettl 2017). Be-

cause the judgment of warmth overlaps morality judgments largely (Fiske 2018), distrusting 
government will influence people's perceived warmth of the public sector. Therefore, news about inequity and mistreatment of immigrants can undermine the government's perceived warmth. Thus, from a psychological perspective, little trust is associated strongly with little warmth.

Compared with a donative and a government-funded organization, a commercial organization may be perceived to the least warm. Such a prejudice derives from people's repugnance against the profit-seeking intention accompanied with fee charging. The psychology literature suggests that people hold a strong anti-profit belief because they perceive that the intention to seek profit is greedy (Lee, Bolton and Winterich 2017) and immoral (Bhattacharjee, Dana and Baron 2017). The anti-profit belief helps explain why people have less trust and relatively more negative perceptions of for-profit SSOs than their traditional nonprofit counterparts. Previous experimental evidence has suggested that people perceived that nonprofit organizations are warmer than are for-profit organizations in the retailing (Aaker, Vohs and Mogilner 2010) and social service industries (Drevs, Tscheulin and Lindenmeier 2014; Xu 2020), as the anti-profit belief makes salient the incompatibility between profit-seeking and traditional donative nonprofits' prosocial mission. For example, commercial nonprofits with a marketing orientation may drift away from unprofitable social goods provision and civic engagement and advocacy (Eikenberry and Kluver 2004; Eikenberry 2009). To sum up, we propose the following hypothesis:

Hypothesis 1: A donative organization is perceived to be warmest, followed by governmentfunded and commercial ones.

Trust in the government can also be associated with its competence. For example, Peters (2012) pointed out that the public's distrust of the government can result from the awareness of scandal, inefficient government performance, and policy failure. In addition, evidence has shown that people often believe that the public sector is incompetent and inefficient automatically and unconsciously (Marvel 2016). Government funding is proposed to be embedded with practices in the public sector which leads to inefficiency. In the nonprofit 
sector, for example, donative nonprofits are more independent than are government-funded nonprofits because the public may consider that the latter are "nonprofits for hire" and under governmental control. When government funding is the dominant revenue source, nonprofits may make strategic adjustments to secure future government funding and thus, drift away from their original goals, such as civic advocacy or serving the community. In consequence, government-funded organizations may fail to represent the community and lose social capital (Guo 2007). Meanwhile, the government's bureaucratic image will also overshadow peoples' perceptions of the SSO's competence. Although receiving government funding may indicate an accreditation of nonprofits' effectiveness, evidence shows that such nonprofits tend to be more bureaucratic to fulfill government funders' requirements of accountability or to secure government resources ( $\mathrm{Lu} 2015)$.

In contrast, a commercial organization may be perceived to be competent than both donative and government-funded organizations. The isomorphic spread of business-like practices in society shows that for-profit organizations, as a major player for the success of capitalism, are perceived to be more competent than are their counterparts in other two sectors (Bromley and Meyer 2017). Not only may income from service fees create sustainable financial resources, but business-like practices associated with commercialization also are suggested to cause the organization to demonstrate greater professionalism. An early discussion proposed that traditional nonprofit organizations are incompetent in general. Salamon (1989) pointed out that philanthropic amateurism in the nonprofit and voluntary sector results from the fact that the beneficiaries call for more moral suasions and religious instruction, but not professional aid or job training. In contrast, nonprofit and public management scholars have proposed that business-like practices may lead to a higher level of innovation, effective service delivery, and efficiency through market competition (Andrews, Boyne and Walker 2011; Dart 2004; Maier, Meyer and Steinbereithner 2016). However, competing theories have suggested that people's anti-profit belief may influence their perceptions of an organization's competence. Based on experimental evidence, Stellar and Willer (2018) 
proposed that the observation of profit-maximizing and immoral activities leads to a perceived failure to understand another person's thoughts and feelings, unwillingness to adapt effectively to changing circumstances, and failure to adhere to a society's most deeply held social norms. Recent evidence also shows that for-profit social enterprises are perceived as incompetent (Xu 2020).

Hypothesis 2: A commercial organization is perceived to be the most competent, followed by donative and government-funded ones.

\section{Resource Publicness and the Prosocial Organization Mission}

In a complex information environment, people do not perceive an organization based on the resource publicness exclusively. Mission statement also matters in organizational perception. Organizations use mission statements to express their roles and commitments and to communicate with stakeholders and the general public. SSOs, not only limited to nonprofits, take different roles in the society (Frumkin 2002). Based on the role depicted in mission statement, people may expect SSOs to align their resource generation strategies with their core roles and values. The alignment between mission and strategies for generating resources influences organizational effectiveness (Moulton and Eckerd 2012). Literature in public and nonprofit management have shown a critical link between mission alignment and organizational success (Resh, Marvel and Wen 2018; Moulton and Eckerd 2012).

There is no consensus on the typology of SSOs' missions. Although SSOs such as hospitals and care centers act as instruments in providing human-based services, their missions are naturally prosocial. However, Brief and Motowidlo (1986) suggested distinguishing prosocial behaviors that are role prescribed from those that are extra. Our hypothesis thus focuses on the prosocial elements beyond the SSO's instrumental role, which is purely service delivery. Broadly, prosocial behaviors include a wide range of actions "with the intention of promoting the welfare of the individual, group, or organization toward which it is directed" (Brief and Motowidlo 1986; p. 711), and people are more likely to consider prosocial orga- 
nizations are warmer and more likely to interact with them (Aaker, Garbinsky and Vohs 2012).

We examine how prosocial elements embedded in the mission statement may moderate people's perception on resource publicness because of the alignment/misalignment. We propose that government funding and donations are more aligned with prosocial elements because funders of these resources are more likely to pursue public benefit. In contrast, service fees are generated through market mechanisms based on the assumption of maximizing self-interests. People may consider service fees misaligned with prosocial elements prescribed in organizations' mission. The mission misalignment will influence people's perception of a SSO adversely. As a result, when a commercial SSO's mission has salient prosocial elements, people may perceive it to be less warm and less competent.

Hypothesis 3: The alignment/misalignment of resource publicness and prosocial mission moderates resource publicness' effects on people's perceptions of the focal organization.

\section{Methods}

\section{Research Overview}

We conducted two survey experiments to test our hypotheses. Study 1 tested the main causal effects of the resource publicness (operationalized as donative, commercial, and government-funded organizations based on whether their major revenues are donations, service fees, or government funds) on people's perceived warmth and competence of the organization $\left(H_{1}\right.$ and $\left.H_{2}\right)$. Study 2 examined whether the alignment between revenue source and organizational mission will moderate the main effects of resource publicness on people's perceptions $\left(H_{3}\right)$. We employed ANOVA and difference-in-means to analyze the results. We also presented the results of OLS regression analysis with covariates in Appendix D.

We set the elderly care industry as the experimental context for both studies because

of its increasing importance for an aging society and its diverse revenue sources that suit 
our research purpose. The elderly care industry in the U.S. is a market where public, for-

profit, and nonprofit organizations compete with each other. Government funding through Medicare and Medicaid, incomes from service fees and private insurance, and donations from foundations and individuals are elderly care centers' three major revenue sources.

\section{Study 1}

\section{Purpose}

Study 1 examined the causal effect of resource publicness on people's perceptions. It is expected that people's perceived warmth and competence vary across donative, commercial, and government-funded SSOs.

\section{Design}

Study 1 developed experimental vignettes that provide information about a hypothetical elder care center in the U.S., called "Midtown Elderly Care Center" (MECC) (see Figure 1). In the experiment, each vignette includes the center's name and mission statement, and a pie chart with legends that show its revenue composition. For the study's purpose, we manipulated the center's major revenue as either "donations" (donative organization), "service fees" (commercial organization), or "governmental funding" (government-funded organization), while other information was held constant across the three groups.

\section{Participants}

A total of 1,051 U.S. adults was recruited through Qualtrics Online Research Panel. The sample's demographic characteristics differed from those of the U.S. population overall - in particular, in which females were overrepresented (82.76\%); however, our analysis showed little systematic difference between male and female subjects' responses. The experimental subjects' detailed demographic information is provided in Appendix A. 
Figure 1: Experimental Vignette

Midtown Elderly Care Center
$\begin{aligned} & \text { The mission of Midtown } \\ & \text { Elderly Care Center is to } \\ & \text { provide health, hope, and } \\ & \text { empowere Center }\end{aligned}$
$\begin{aligned} & \text { seniors help themselves and } \\ & \text { others. }\end{aligned}$

Midtown Elderly Care Center
The mission of Midtown
Elderly Care Center is to
provide health, hope, and
empowerment to enable of Midtown
seniors help themselves and
others.

Midtown Elderly Care Center
The mission of Midtown
Elderly Care Center is to
provide health, hope, and
empowerment to enable
seniors help themselves and
others.

\section{Procedure}

The experiment was conducted in the Qualtrics online platform. First, participants were presented with either a donative, commercial, or government-funded organization randomly and read the vignette information. Then, they were asked about their perceptions of the MECC's warmth and competence. We followed Aaker et al. (2010) and adopted SCM to capture perceptions. We asked subjects, "To what extent do you believe that Midtown Elderly Care Center is __ ?" with respect to six traits, among which three comprised 
the warmth index (warm, kind, generous; $\alpha=0.93$ ) and the other three the competence index (competent, effective, efficient; $\alpha=0.93$ ). Each trait's assessment was reported on a 0 to 100 scale. Factor analysis with varimax rotation confirmed that six instruments loaded on two unique factors (see Appendix B for the results). The order of the instruments that measured warmth and competence was randomized to avoid the ordering effect. Finally, the subjects were asked to report their sociodemographic characteristics, including gender, age, race, educational background, and income levels.

\section{Results}

Warmth. A one-way ANOVA showed that the organization's resource publicness had a main effect on people's perceived warmth $\left(p<0.001, \eta^{2}=0.03\right)$. Specifically, people reported significantly higher warmth when presented with the donative MECC compared with the commercial $\left(t_{664}=5.51, p<0.001, d=0.43\right)$ and government-funded organizations $\left(t_{704}=3.23, p=0.001, d=0.24\right)$. Meanwhile, people perceived that the government-funded MECC was warmer than the commercial $\left(t_{728}=2.42, p=0.02, d=0.19\right)$ (Figure 2).

Competence. The ANOVA also demonstrated a significant main effect of resource publicness on people's perceptions of the organization's competence $\left(p<0.001, \eta^{2}=0.016\right)$. In particular, the donative organization was judged to be more competent than the commercial $\left(t_{663}=4.19, p<0.001, d=0.32\right)$ and the government-funded $\left(t_{704}=1.94, p=0.05\right.$, $d=0.15)$. In addition, the government-funded organization was perceived to be more competent than the commercial $\left(t_{727}=2.26, p=0.02, d=0.17\right)$ (Figure 2$)$.

\section{Discussion}

The results from Study 1 suggested that people's perceived warmth and competence varied significantly across donative, commercial, and government-funded elderly care center. Particularly, people perceived that the donative elderly care center was warmer than the commercial and the government-funded ones. Meanwhile, the donative elderly care center 
Figure 2: Study 1: Warmth and Competence
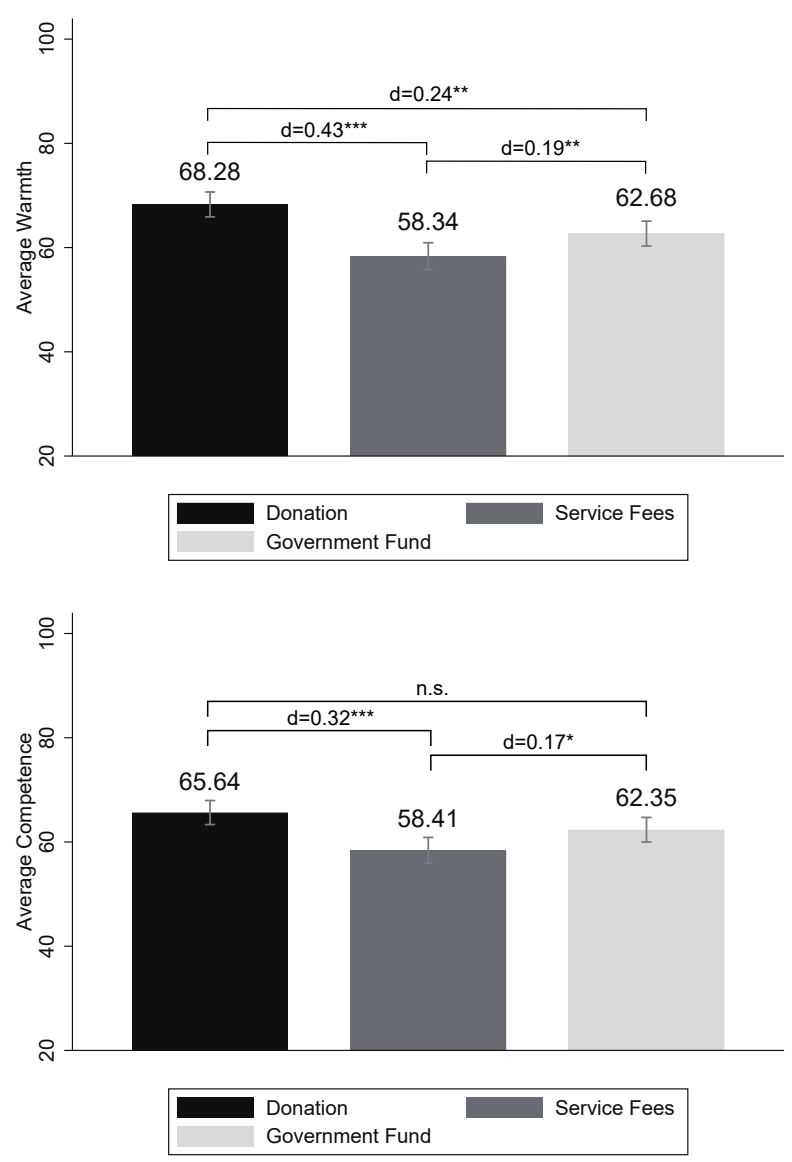

Note: 1) Means are presented for each experimental condition; 2) Cohen's $d$ s are reported as a measure of effect size; 3$\left.){ }^{*} p<.05,{ }^{* *} p<.01,{ }^{* * *} p<.001 ; 4\right)$ n.s. means not statistically significant.

was also perceived to be more competent than the government-funded. However, contrary to our hypothesis, the donative organization was perceived to be significantly more competent than the commercial organization. Thus, in general, these findings confirmed our expectation: Different organizational resource publicness will trigger significantly different perceptual judgments. Additional regression analysis including covariates shows the same results (see Appendix D). 


\section{Study 2}

\section{Purpose}

Study 2 examined the way the alignment/misalignment between resource publicness and the organization's prosocial mission influences people's perceptions of the focal organization. It is expected that people will perceive organizations with a higher level of alignment between mission and resource publicness (for example, donation and government funding are aligned with prosocial mission, whereas service fee is aligned with pure instrumental mission) to be warmer and more competent than those with a lower alignment level. The results may provide us an alternative explanation of why people's perceptions vary across different levels of resource publicness.

\section{Design}

We conducted a preregistered experiment that applied a 3 (revenue source: donations vs. service fees vs. government funding) $\times 2$ (prosocial mission: instrumental mission vs. prosocial mission) between-subject design. Similar to Study 1, we used the hypothetical MECC as the experimental context, and asked subjects to read information in vignettes and answer a set of outcome questions. The organization's resource publicness was manipulated following the strategy in Study 1 (see Appendix C for the vignettes used for Study 2). The organization's instrumental and prosocial mission was manipulated by presenting different mission statements. The instrumental mission statement reads:

"Midtown Elderly Care Center offers caring services, including assisted living, senior care, and nursing homes to older adults, supported by well-trained and licensed nurses." The prosocial mission statement reads:

"Midtown Elderly Care Center strives to provide caring services, support, hope, and empowerment to enable seniors, and advocates for continues improvement in the health in the community." 
In addition, to test the organizational mission's moderating effect, Study 2 advanced Study 1 in the following ways. First, Study 2 advanced instruments to measure perceived warmth and competence. We adjusted the measurement scale of the warmth and competence indicators from "0 to 100 " to "-50 to 50", which allowed us to capture whether respondents held a positive or negative attitude toward the focal organization, although it is mathematically identical to the measurement in Study 1. Second, to capture the practical implications of perceptual differences, Study 2 measured people's willingness to purchase from, and donate to, the organization. The willingness to engage in both actions was also measured on a Likert scale $(-50=$ completely unwilling to $50=$ completely willing $)$.

Before Study 2, a pretest was conducted to examine the effect of the instrumental vs. prosocial mission on people's perceptions. A total of 102 subjects was recruited from Amazon Mechanical Turk (MTurk), and the difference-in-means test suggested that people perceived that the organization with an prosocial mission statement was warmer than that with an instrumental mission statement $\left(M_{\text {pro }}=30.53, S D=15.17\right.$ vs. $\quad M_{\text {ins }}=23.81$, $\left.S D=16.46, t_{85}=1.93, p=0.06, d=0.42\right)^{1}$. However, the types of mission had no significant effects on perceived competence. In general, the results of the pretest confirmed in part our expectation that people's perceptions of an instrumental organization differ from those of an expressive organization.

\section{Participants}

615 subjects were recruited from MTurk, and the subjects in the pretest were not allowed to participate in Study 2. After eliminating incomplete responses and subjects who failed the attention check, the final sample size for Study 2 was 525 (52.57\% female, $\left.M_{\text {age }}=39\right)$. Detailed sample characteristics are reported in Appendix A.

\footnotetext{
${ }^{1}$ Power analysis using GPower 3.1.9.2 suggested that a sample with 292 subjects will provide a statistically significant results with the same effect size, with a power of .95 .
} 


\section{Procedure}

The experiment was delivered through a Qualtrics survey. After the introduction, the participants were assigned randomly to one of six experimental conditions in which the hypothetical organization's mission statement and major revenue source were manipulated. To ensure that they paid attention to both the manipulated information, mission statements, and revenue structure of the organization, each source of information appeared on separate pages and was presented in random order. After reading the information, participants were asked to answer the same questions that measure perceived warmth $(\alpha=0.92)$ and competence $(\alpha=0.93)$. They were also asked to report their willingness to send a family member to the organization if needed and willingness to donate on a scale from -50 to 50 . The survey instruments that measured the dependent variables were counterbalanced. After completing all of the steps above, the participants reported their demographic information and was compensated $\$ 0.50$ for completion.

\section{Results}

Warmth. A two-way ANOVA demonstrated a statistically significant main effect of major revenue source on people's perceived warmth of the focal organization $(p<0.001$, $\left.\eta^{2}=0.04\right)$. Specifically, the donative organization was perceived to be significantly warmer than was the commercial organization $\left(M_{d o n}=25.70, S D=14.40\right.$ vs. $\quad M_{f e e}=16.51$, $\left.S D=18.82, t_{349}=5.15, p<0.001, d=0.55\right)$ and the government-funded organization $\left(M_{\text {gov }}=20.60, S D=19.13, t_{351}=2.84, p=0.005, d=0.30\right)$. In addition, the governmentfunded organization was considered to be warmer than was the commercial organization $\left(t_{344}=2.00, p=0.05, d=0.22\right)$. Unlike our pretest results, the types of organizational mission had no significant main effect, and there was no interaction effect between mission types and major revenue sources on perceived warmth. The subgroups' analytical results are presented in Figure 3 and Table 1.

Competence. Our analysis revealed a slight main effect of major revenue source on 
Figure 3: Study 2: Warmth and Competence
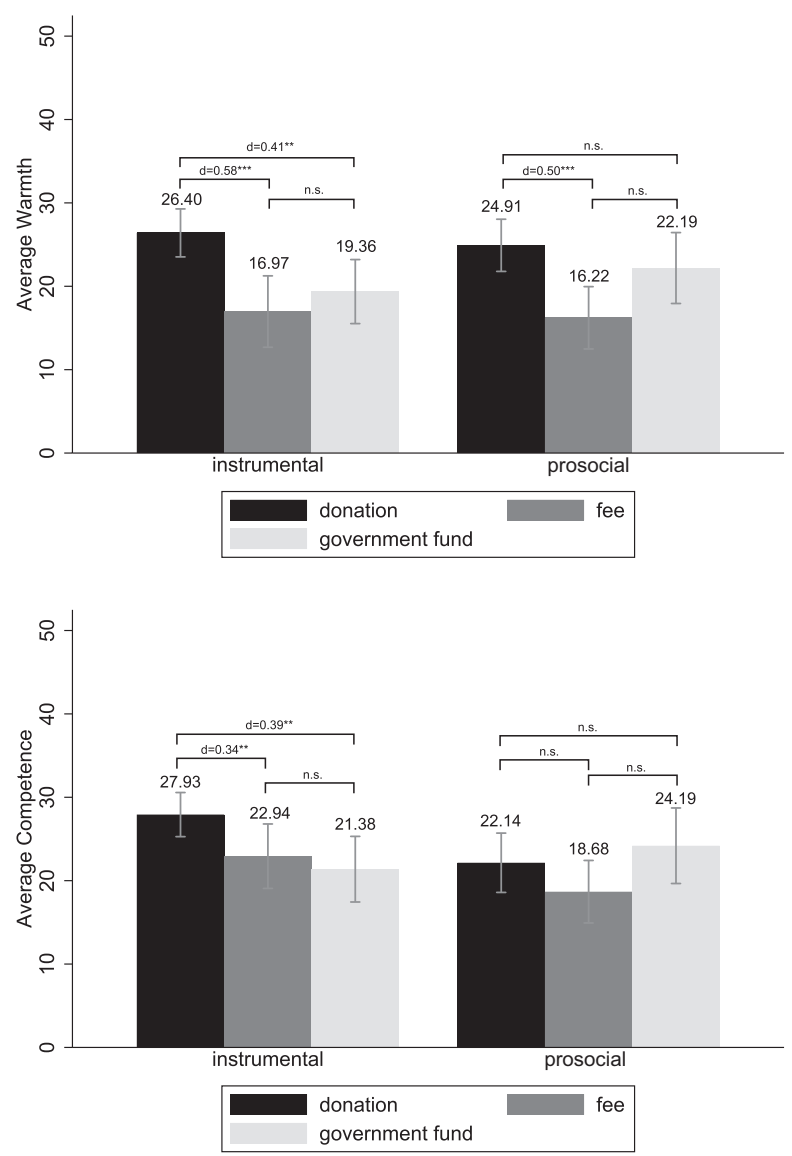

Note: 1) Means are presented for each experimental condition; 2) Cohen's $d$ s are reported as a measure of effect size; 3$\left.)^{*} p<.05,{ }^{* *} p<.01,{ }^{* * *} p<.001 ; 4\right)$ n.s. means not statistically significant.

people's perceptions of the organization's competence $\left(p=0.09, \eta^{2}=0.009\right)$. Specifically, people perceived that only the donative organization was more competent than the commercial $\left(M_{\text {don }}=25.21, S D=15.09\right.$ vs. $\quad M_{f e e}=20.34, S D=18.36, t_{349}=2.73$, $p=0.007)$. There was no significant difference between government-funded organization's perceived competence $\left(M_{\text {gov }}=22.61, S D=19.94\right)$ and that of the donative and commercial organizations. The ANOVA did not confirm our expectation of the mission types' effects. Findings of moderating interaction effect between the mission types and the major revenue sources were mixed $\left(p=0.06, \eta^{2}=0.01\right)$. When they read a prosocial mission, people perceived that the government-funded organization was more competent than was 
Table 1: Study 2: Descriptive Statistics and ANOVA Results $(N=$ 525)

\begin{tabular}{|c|c|c|c|c|}
\hline \multicolumn{5}{|l|}{ Warmth } \\
\hline & & Donation & Service Fee & Government Fund \\
\hline \multirow[t]{2}{*}{ Instrumental } & Mean & 26.40 & 16.97 & 19.36 \\
\hline & $\mathrm{SD}$ & 14.27 & 17.85 & 19.35 \\
\hline \multirow[t]{2}{*}{ Prosocial } & Mean & 24.91 & 16.22 & 22.19 \\
\hline & $\mathrm{SD}$ & 14.60 & 19.49 & 18.86 \\
\hline ANOVA & & $d f$ & $F$ & $\eta^{2}$ \\
\hline Resource & & 2 & $11.39^{* * *}$ & .042 \\
\hline Mission & & 1 & .02 & n.s. \\
\hline Resource $\times$ Mission & & 2 & .74 & n.s. \\
\hline \multicolumn{5}{|l|}{ Competence } \\
\hline & & Donation & Service Fee & Government Fund \\
\hline \multirow[t]{2}{*}{ Instrumental } & Mean & 27.93 & 22.94 & 21.38 \\
\hline & $\mathrm{SD}$ & 13.12 & 16.11 & 19.82 \\
\hline \multirow[t]{2}{*}{ Prosocial } & Mean & 22.14 & 18.68 & 24.19 \\
\hline & SD & 16.59 & 19.55 & 20.10 \\
\hline ANOVA & & $d f$ & $F$ & $\eta^{2}$ \\
\hline Resource & & 2 & 2.42 & n.s. \\
\hline Mission & & 1 & 2.35 & n.s. \\
\hline Resource $\times$ Mission & & 2 & 2.86 & n.s. \\
\hline
\end{tabular}

Note: 1$\left.)^{*} p<.05,{ }^{* *} p<.01,{ }^{* * *} p<.001 ; 2\right)$ n.s. means not statistically significant.

the commercial $\left(M_{\text {gov }}=24.19, S D=20.10\right.$ vs. $M_{f e e}=18.68, S D=19.55, t_{179}=1.85$, $p=0.07, d=0.28)$. Under the instrumental mission condition, people reported that the donative organization was significantly more competent than were its government-funded $\left(M_{\text {don }}=27.93, S D=13.12\right.$ vs. $\left.M_{\text {gov }}=21.38, S D=19.82, t_{191}=2.70, p=0.01, d=0.39\right)$ and commercial counterparts $\left(M_{f e e}=22.94, S D=16.11, t_{160}=2.17, p=0.03, d=0.34\right)$. The subgroups' analytical results are presented in Figure 3 and Table 1.

Willingness to Donate. A two-way ANOVA demonstrated that the major revenue sources had a significant effect on people's willingness to donate to the organization $(p<$ 0.001, $\left.\eta^{2}=0.036\right)$. Specifically, while there was no statistical difference between the donative and the government-funded organization, people were significantly less willing to donate to 
the commercial organization $\left(M_{f e e}=-0.42, S D=28.46\right.$ vs. $M_{d o n}=12.76, S D=27.01$, $t_{349}=4.45, p<0.001, d=0.48 ;$ vs. $M_{\text {gov }}=9.31, S D=26.89, t_{344}=3.27, p=0.001$, $d=0.35)$. However, we found no effect of the mission type or its interaction with the major revenue source on willingness to donate. The subgroups' analytical results are presented in Figure 4 and Table 2.

Willingness to Purchase. The two-way ANOVA found no main effect of the organization's major revenue source on people's willingness to purchase. In addition, it also revealed no significant difference between the effects of the instrumental and prosocial mission. Finally, the interaction between the major revenue source and the mission type had no significant influence on people's willingness to purchase. Each subgroups' analytical results are presented in Figure 4 and Table 2.

\section{Discussion}

The results from Study 2 replicated the findings in Study 1: People judged the organization differently depending on the resource publicness categories. Again, our results showed that people perceived that the donative organization was warmer and more competent than were its commercial and the government-funded counterparts. We also found that the major revenue source influenced people's willingness to donate, but not their willingness to purchase significantly. Regression analysis including covariates (including previous experience with elderly care center) also shows the same results (see Appendix D).

The findings from Study 2 reaffirmed the main effect of resource publicness on people's perception. In addition, hypothesis 3 which focuses on the alignments between the resource publicness and organizational mission was partially supported. Although there was no significant findings on warmth, people do perceive the commercial elderly care center with prosocial mission, which is a theoretical misalignment between organizational mission and resource publicness, the least competent across all conditions. 
Figure 4: Study 2: Willingness to Donate and to Purchase
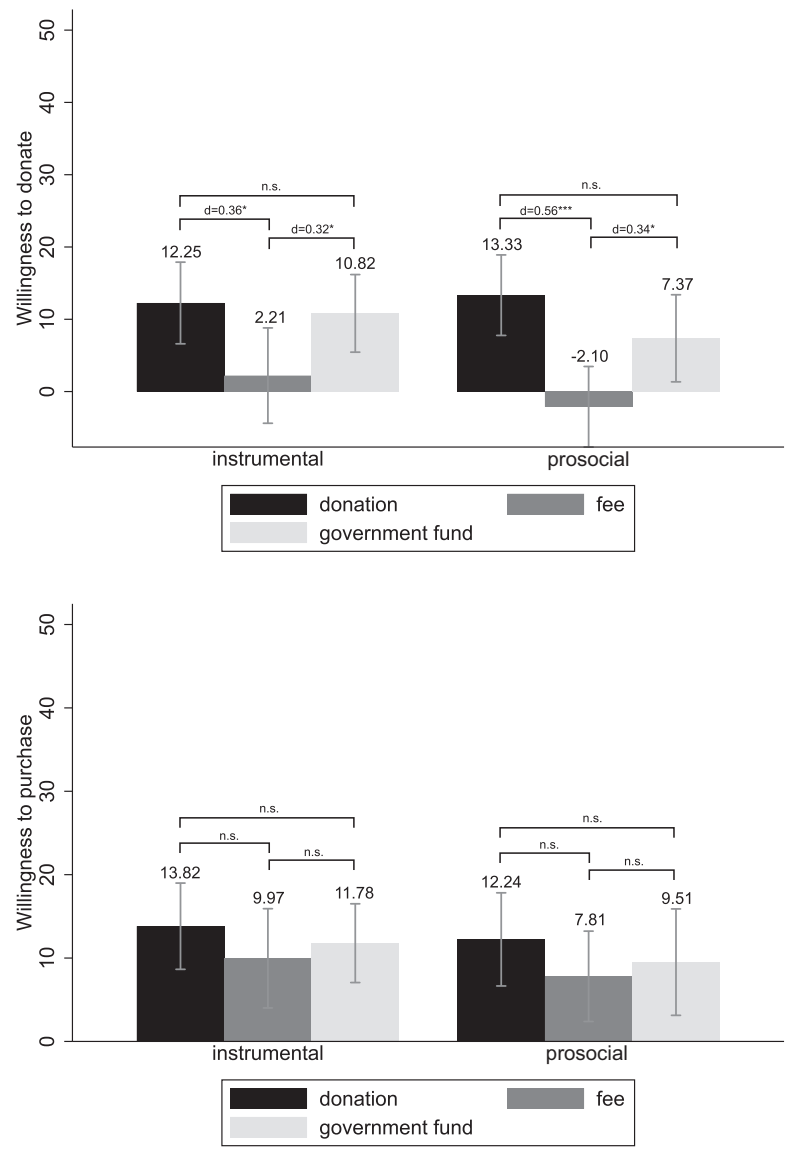

Note: 1) Means are presented for each experimental condition; 2) Cohen's $d$ s are reported as a measure of effect size; 3$\left.){ }^{*} p<.05,{ }^{* *} p<.01,{ }^{* * *} p<.001 ; 4\right)$ n.s. means not statistically significant.

\section{Conclusion}

In this study, we examined the effects of resource publicness on people's judgment on elderly care centers, an example of SSOs in the U.S. Using two experiments, we tested a set of hypotheses and provided new evidence of the way resource publicness influences peoples' perceptions and service choices. Although publicness theory focuses on both ownership and dimensional publicness, scholars have paid greater attention to the former. Illustrated by our finding on resource publicness, dimensional publicness may capture more nuanced variations of organizations and help explain the increasingly blurred boundaries between organizations 
Table 2: Study 2: Descriptive Statistics and ANOVA Results $(N=$ $525)$

\begin{tabular}{|c|c|c|c|c|}
\hline \multicolumn{5}{|c|}{ Willingness to Donate } \\
\hline & & Donation & Service Fee & Government Fund \\
\hline \multirow[t]{2}{*}{ Instrumental } & Mean & 12.25 & 2.21 & 10.82 \\
\hline & $\mathrm{SD}$ & 28.02 & 27.48 & 27.05 \\
\hline \multirow[t]{2}{*}{ Prosocial } & Mean & 13.33 & -2.10 & 7.37 \\
\hline & $\mathrm{SD}$ & 25.98 & 29.07 & 26.73 \\
\hline ANOVA & & $d f$ & $F$ & $\eta^{2}$ \\
\hline Resource & & 2 & $9.60^{* * *}$ & .036 \\
\hline Mission & & 1 & .84 & n.s. \\
\hline Resource $\times$ Mission & & 2 & .48 & n.s. \\
\hline \multicolumn{5}{|c|}{ Willingness to Purchase } \\
\hline & & Donation & Service Fee & Government Fund \\
\hline \multirow[t]{2}{*}{ Instrumental } & Mean & 13.82 & 9.97 & 11.78 \\
\hline & $\mathrm{SD}$ & 25.67 & 24.80 & 23.79 \\
\hline \multirow[t]{2}{*}{ Expressive } & Mean & 12.24 & 7.81 & 9.51 \\
\hline & $\mathrm{SD}$ & 26.05 & 28.27 & 28.31 \\
\hline$A N O V A$ & & $d f$ & $F$ & $\eta^{2}$ \\
\hline Resource & & 2 & 1.08 & n.s. \\
\hline Mission & & 1 & .75 & n.s. \\
\hline Resource $\times$ Mission & & 2 & .01 & n.s. \\
\hline
\end{tabular}

Note: 1$\left.)^{*} p<.05,{ }^{* *} p<.01,{ }^{* * *} p<.001 ; 2\right)$ n.s. means not statistically significant.

with different legal statuses. More importantly, the study took one step further to extend the dimensional publicness theory beyond the organization itself by linking it to the external audiences' perceptions and reactions. One of the major caveats of publicness theories in informing practical strategic management is that outcomes can be changed by changing the design of institutions and configurations of institutional environments (Bozeman and Moulton 2011; p. i374). In the context of public service delivery, reactions from an organization's external environment may determine whether it can achieve the realized publicness (Moulton 2009). Institutional theories place great emphasis on the way the focal organization's external environment influences its organizational effectiveness (Pfeffer and Salancik 2003). This issue is particularly urgent, given the fact that service providers are facing more fierce 
competition for the limited resources in the environment that they need to survive.

The findings from two studies supported hypotheses on perceived warmth: commercial and government-funded organizations were perceived to be less warm than were donative organizations. From a financial management perspective, this implies that donations might be a more favorable revenue source for social service providers. Consistent with previous findings, the resource collectiveness is important for organizations that provide collective goods and services that benefit the public (Weisbrod 1997). These findings respond to concerns about the increasing commercial incomes and government funding in the traditional nonprofit sector (Lipsky and Smith 1993; Weisbrod 2004).

People perceived that government-funded organizations were less competent than were donative ones, which is consistent with previous findings that people's judgments of public organizations' performance are biased (Hvidman and Andersen 2015; Marvel 2016). Our results also demonstrated that commercial organizations were perceived to be less competent than were both the donative and government-funded organizations. These results contradict previous findings about the nonprofit sector's amateurism and the private sector's professionalism. Previous literature on organizational stereotypes has suggested that nonprofits are warm, but incompetent (Aaker, Vohs and Mogilner 2010), but our experiment revealed that organizations supported by donations are perceived to be both warm and competent. A possible explanation is that people's perceptions of an organization are contextbased, and one important contextual factor is the service area. For some services, such as the elder care service in our experiment, commercial or government-funded organizations are perceived less favorably than are donative organizations. Such a perceptual difference may be a prototypical impression attributable to traditional nonprofit organizations' long-term efforts in providing caring services. We recommend further conceptual replications across different social services areas in various cultural and legal contexts. Indeed, factors such as legal definitions, cultural inheritance, and state policies all contribute to the particular stereotypical perception of organizations (DiMaggio and Anheier 1990). 
It is also possible that the public maintains a "normative publicness" (Bozeman and Moulton 2011) for SSOs. As we expected, Study 2 shows that people perceive the focal organization to be less competent when there is a theoretical misalignment between the resource publicness (service fee) and organizational mission (prosocial). As people build expectations of the organization based on its mission, they may perceive the organization negatively when organizational characteristics and behavior fail their expectations. While our study particularly articulates the SSO's mission using a prosocial tone that raises emotional reactions, an important question is whether people will follow the same logic to judge other SSOs with prosocial missions. Therefore, our findings need to be interpreted with caution. Our hypothesis of mission-resource publicness misalignment may help to explain the inconsistency of people's perceptions on nonprofit and for-profit organizations in different markets. Future studies need to investigate how people react to combinations of dimensional and ownership publicness that contradict to their stereotypical expectations.

Our study implies a potential association between resource publicness and ownership publicness when the publicness model is extended beyond the organization. Our results partially mirror previous experimental studies on sector difference, where ownership publicness is manipulated (Xu 2020; Andersen and Hjortskov 2016; Lee, Bolton and Winterich 2017). While resource publicness can be a dimension parallel with ownership in the traditional publicness model, it could have a strong association with ownership publicness through stereotypical judgments. Such an association may open doors for research on dimensional publicness at a micro-level, as people are able to associate other factors with ownership based on their stereotypical understanding of, for instance, the organization's branding or leader. In addition, such connections may exist in all decision-making processes and, in turn, create substantial cognitive biases. Thus, future studies on publicness theory should pay more attention to dimensional publicness that can be associated stereotypically with their ownership.

Our study informs organizational practices by operationalizing people's perceptions 
as warmth and competence. By capturing the nuances of people's perceptual reactions to the major revenue source, SSOs' managers are able to make strategic adjustments to correct the perceptual problem associated with financial information. Our experiment showed that the major revenue sources have greater effects on perceived warmth than on perceived competence. Thus, we advise managers to use strategies of communication, marketing, and organizational branding to manage their image of warmth. Indeed, perceived warmth proved to be a predictor of people's emotions and behaviors before perceived competence (Cuddy, Glick and Beninger 2011). For commercial and government-funded SSOs, both of which are perceived to be less warm than are the donative ones, more actions that are associated with warmth perception should be adopted, including community engagement, participatory decision-making, and other prosocial activities that generate social capital. In addition, it is necessary to note that managers should design and implement warmth management strategies based on feedback from their audience through frequent interactions and communications. Recent experimental evidence has shown that people perceive the same behavior on the part of organizations with high or low warmth in significantly different ways - prosocial behaviors high-warmth organizations demonstrate acquired more approval from the public, while the same behaviors low-warmth organizations exhibited were perceived as non-altruistic and exchange-intended instead (Gershon and Cryder 2018). In our case, a particular communication strategy that works for a government-funded organization may lead to different public reactions to the same strategy when used by a commercial one.

It is important to notice that our study has a number of limitations that weaken the ability to generalize the findings, but offer opportunities for further studies. First, we used two convenience sample from online research panels. Therefore, our experimental results should be interpreted more conservatively because they did not represent the entire population. The results from this study may also differ from those of studies that use other stakeholder groups and other subareas of social services. Thus, more experimental studies are necessary to validate the results. Second, our study used a hypothetical organization 
with highly simplified financial information to examine the treatment's effect. In reality, it can be expected that other factors may either strengthen or weaken the major revenue source's effects, such as information sources and framing, as well as social influences in the complex social network.

Despite these limitations, the study provides causal evidence that resource publicness matters in organizational perceptions. More importantly, the study raises concerns for a classic yet unanswered question in public administration: how distinct should public organizations be from private and nonprofit organizations and to what extent does organizational publicness matter for social service delivery? Given our evidence on the alignment between resource publicness and organizational mission, it is possible that people may consider government-funded organizations as a more legitimate provider of social service, which contradicts the fact that the number of fee-based service providers is growing. Although the government is making great efforts to hold social service providers accountable, people's relative repugnance against the fee-based model may still create uncertainty and insecurity regarding service equity, effectiveness, and efficiency. As people are less likely to react to organizations that lack institutional legitimacy, biases on the level of publicness will create congestions for certain types of service providers and foster inequitable access to important services. Therefore, we call for more behavioral studies on organizational publicness, especially from a dimensional perspective, to advance our understanding of sector differences in theory and optimize social service delivery in practice. 


\section{References}

Aaker, Jennifer, Kathleen D Vohs and Cassie Mogilner. 2010. "Nonprofits Are Seen as Warm and For-Profits as Competent: Firm Stereotypes Matter." Journal of Consumer Research $37(2): 224-237$.

Aaker, Jennifer L, Emily N Garbinsky and Kathleen D Vohs. 2012. "Cultivating admiration in brands: Warmth, competence, and landing in the "golden quadrant"." Journal of Consumer Psychology 22(2):191-194.

Abele, Andrea E and Bogdan Wojciszke. 2007. "Agency and Communion From the Perspective of Self Versus Others." Journal of Personality and Social Psychology 93(5):751-763.

Amirkhanyan, Anna A., Hyun Joon Kim and Kristina T. Lambright. 2008. "Does the Public Sector Outperform the Nonprofit and For-Profit Sectors? Evidence from a National Panel Study on Nursing Home Quality and Access." Journal of Policy Analysis and Management $27(2): 326-353$.

Andersen, Simon Calmar and Morten Hjortskov. 2016. "Cognitive Biases in Performance Evaluations." Journal of Public Administration Research and Theory (July):647-662.

Andrews, Rhys, George A Boyne and Richard M Walker. 2011. "Dimensions of publicness and organizational performance: A review of the evidence." Journal of public administration research and theory 21(suppl_3):i301-i319.

Bekkers, René. 2003. "Trust, accreditation, and philanthropy in the Netherlands." Nonprofit and Voluntary Sector Quarterly 32(4):596-615.

Bhattacharjee, Amit, Jason Dana and Jonathan Baron. 2017. "Anti-Profit Beliefs: How People Neglect the Societal Benefits of Profit." Journal of Personality and Social Psychology 113(5):671-696.

URL: http://doi.apa.org/getdoi.cfm?doi=10.1037/pspa0000093

Bordalo, Pedro, Katherine Coffman, Nicola Gennaioli and Andrei Shleifer. 2016. "Stereotypes." The Quarterly Journal of Economics 131(4):1753-1794.

Bozeman, Barry. 1987. All organizations are public: Bridging public and private organizational theories. Jossey-Bass Inc Pub.

Bozeman, Barry and Stephanie Moulton. 2011. "Integrative publicness: A framework for public management strategy and performance." Journal of public administration research and theory 21(suppl_3):i363-i380.

Bozeman, Barry and Stuart Bretschneider. 1994. "The "publicness puzzle" in organization theory: A test of alternative explanations of differences between public and private organizations." Journal of public administration research and theory 4(2):197-224. 
Brewer, Gene A. and Gene A. Brewer Jr. 2011. "Parsing public/private differences in work motivation and performance: An experimental study." Journal of Public Administration Research and Theory 21(SUPPL. 3).

Brief, Arthur P and Stephan J Motowidlo. 1986. "Prosocial organizational behaviors." Academy of management Review 11(4):710-725.

Bromley, Patricia and John W. Meyer. 2017. "“They are all organizations": The cultural roots of blurring between the nonprofit, business, and government sectors." Administration and Society 49(7):939-966.

Chernev, Alexander. 2015. "Doing Well by Doing Good: The Benevolent Halo of Corporate Social Responsibility." Journal of Consumer Research 41(April):1412-1425.

Cuddy, Amy J. C., Susan T Fiske and Peter Glick. 2007. "The BIAS map: behaviors from intergroup affect and stereotypes." Journal of personality and social psychology 92(4):631648.

Cuddy, Amy J.C., Peter Glick and Anna Beninger. 2011. "The dynamics of warmth and competence judgments, and their outcomes in organizations." Research in Organizational Behavior 31:73-98.

Dart, Raymond. 2004. "The legitimacy of social enterprose." Nonprofit Managment and Leadership 14(4):411-424.

Deephouse, David L. and Mark Suchman. 2008. Legitimacy in Organizational Institutionalism. In The SAGE Handbook of Organizational Institutionalism, ed. R. Greenwood, C. Oliver, R. Suddaby and K Sahlin-Andersson. SAGE. pp. 49-77.

DiMaggio, Paul J. and Helmut K. Anheier. 1990. "The Sociology of Nonprofit Organizations and Sectors." Annual Review of Sociology 16:137-159.

Drevs, Florian, Dieter K. Tscheulin and Jörg Lindenmeier. 2014. "Do Patient Perceptions Vary With Ownership Status? A Study of Nonprofit, For-Profit, and Public Hospital Patients." Nonprofit and Voluntary Sector Quarterly 43(1):164-184.

URL: http://journals.sagepub.com/doi/10.1177/0899764012458179

Eikenberry, Angela M. 2009. "Refusing the market: A democratic discourse for voluntary and nonprofit organizations." Nonprofit and Voluntary Sector Quarterly 38(4):582-596.

URL: http://journals.sagepub.com/doi/10.1177/0899764009333686

Eikenberry, Angela M and Jodie Drapal Kluver. 2004. "The marketsization of the nonprofit sector: Civil society at risk?" Public Administration REVIEW 64(2):132-140.

Fiske, Susan T. 2018. "Stereotype Content: Warmth and Competence Endure." Current Directions in Psychological Science 27(2):67-73.

Fiske, Susan T., Amy J C Cuddy and Peter Glick. 2007. "Universal dimensions of social cognition: warmth and competence." Trends in Cognitive Sciences 11(2):77-83. 
Frumkin, Peter. 2002. On Being Nonprofit: A Conceptual and Policy Primer. Cambridge, MA: Havard University Press.

Gershon, Rachel and Cynthia Cryder. 2018. "Goods Donations Increase Charitable Credit for Low-Warmth Donors." Journal of Consumer Research 45:451-469.

URL: http://academic.oup.com/jcr/advance-article/doi/10.1093/jcr/ucx126/4781295

Guo, Chao. 2007. "When Government Becomes the Principal Philanthropist: The Effects of Public Funding on Patterns of Nonprofit Governance." Public Administration Review $67(3): 458-71$.

Handy, Femida, Ram A Cnaan, Lesley Hustinx, Chulhee Kang, Jeffrey L Brudney, Debbie Haski-Leventhal, Kirsten Holmes, Lucas C P M Meijs, Anne Birgitta Pessi, Bhagyashree Ranade, Naoto Yamauchi and Sinisa Zrinscak. 2010. "A Cross-Cultural Examination of Student Volunteering: Is It All About Résumé Building?" Nonprofit and Voluntary Sector Quarterly 39(3):498-523.

URL: http://nvs.sagepub.com/content/39/3/498.abstract

Hansmann, Henry B. 1980. "The Role of Nonprofit Enterprise." the Yale Law Journal $89(5): 835-901$.

Hvidman, Ulrik and Simon Calmar Andersen. 2015. "Perceptions of Public and Private Performance: Evidence from a Survey Experiment." Public Administration Review 76(1):111 $-120$.

URL: http://dx.doi.org/10.1111/puar.12441

Jilke, Sebastian, Wouter van Dooren and Sabine Rys. 2018. "Discrimination and Administrative Burden in Public Service Markets: Does a Public-Private Difference Exist?" Journal of Public Administration Research and Theory Forthcomin(March):1-17.

URL: https://papers.ssrn.com/sol3/papers.cfm?abstract_id=3107998

Kettl, Donald F. 2017. Can Governments Earn Our Trust. Wiley.

Lee, Saerom, Lisa E. Bolton and Karen Page Winterich. 2017. "To profit or not to profit? The role of greed perceptions in consumer support for social ventures." Journal of Consumer Research 44(4):853-876.

Li, Huafang. 2020. "Communication for coproduction: a systematic review and research agenda." Journal of Chinese Governance 5(1):110-135.

Li, Huafang and Lindsey McDougle. 2017. "Information source reliance and charitable giving decisions." Nonprofit Management and Leadership 27(4):549-560.

Lipsky, M. and S. R. Smith. 1993. Nonprofits for hire: the welfare state in the age of contracting. Harvard University Press.

Lu, Jiahuan. 2015. "Which Nonprofit Gets More Government Funding? Nonprofit's Organizational Attributes and Their Receipts of Government Funding." Nonprofit Management \& Leadership 25(3):297-310. 
Maier, Florentine, Michael Meyer and Martin Steinbereithner. 2016. "Nonprofit organizations becoming business-Like: A systematic review." Nonprofit and Voluntary Sector Quarterly 45(1):64-86.

Marvel, John D. 2016. "Unconscious Bias in Citizens Evaluations of Public Sector Performance." Journal of Public Administration Research and Theory 26(1):143-158.

Meier, Kenneth J., Austin P. Johnson and Seung Ho An. 2019. "Perceptual Bias and Public Programs: The Case of the United States and Hospital Care." Public Administration Review 00:1-9.

Meier, Kenneth J and Seung-Ho An. 2020. "Sector bias in public programs: US nonprofit hospitals." Journal of Behavioral Public Administration 3(1):1-8.

Miller, Susan M. and Stephanie Moulton. 2014. "Publicness in policy environments: A multilevel analysis of substance abuse treatment services." Journal of Public Administration Research and Theory 24(3):553-589.

Moulton, Stephanie. 2009. "Putting together the publicness puzzle: A framework for realized publicness." Public Administration Review 69(5):889-900.

Moulton, Stephanie and Adam Eckerd. 2012. "Preserving the publicness of the nonprofit sector: Resources, roles, and public values." Nonprofit and Voluntary Sector Quarterly 41(4):656-685.

Niskanen, William. 1971. Bureaucracy and Represntative Government. Hawthorne, NY: Aldine de Gruyter.

O'Regan, Katherine and Sharon Oster. 2002. "Does Government Funding Alter Nonprofit Governance? Evidence from New York City Nonprofit Contractors." Journal of Policy Analysis and Management 21(3):359-379.

Peters, G. B. 2012. American Public Policy: Promise and Performance. SAGE Publications Inc.

Pfeffer, Jeffery and Gerald R. Salancik. 2003. The External Control of Organizations: A Resource Dependence Perspective. Stanford: Stanford University Press.

Rainey, Hal G. 1979. "Perceptions of incentives in business and government: Implications for civil service reform." Public administration review pp. 440-448.

Resh, William G, John D Marvel and Bo Wen. 2018. "The persistence of prosocial work effort as a function of mission match." Public Administration Review 78(1):116-125.

Salamon, L M. 1989. "Of Market Failure, Voluntary Failure and Third-Party Government: Toward a Theroy of Government-Nonprofit realtions in the Modern Welfare State." Nonprofit and Voluntary Sector Quarterly 16(1-2):29-49. 
Salamon, Lester M. 1993. "The Marketization of Welfare: Changing Nonprofit and ForProfit Roles in the American Welfare State." Social Service Review 67(1):16-39.

URL: http://www.jstor.org.ezproxy.webfeat.lib.ed.ac.uk/stable/30012181

Saxton, Gregory D., Daniel G. Neely and Chao Guo. 2014. "Web Disclosure and the Market for Charitable Contributions." Journal of Accounting and Public Policy 33(2):127-144. URL: http://dx.doi.org/10.1016/j.jaccpubpol.2013.12.003

Seemann, Ann Kathrin, Simone Renner, Florian Drevs and Martin Dietrich. 2014. "Ownership status, symbolic traits, and housing association attractiveness: evidence from the German residential market." International Journal of Housing Policy 14(4):411-426.

Stellar, Jennifer E. and Robb Willer. 2018. "Unethical and inept? The influence of moral information on perceptions of competence." Journal of Personality and Social Psychology 114(2):195-210.

Suddaby, Roy, Alex Bitektine and Patrick Haack. 2017. "Legitimacy." Academy of Management Annals 11(1):451-478.

Todorov, A., Anesu N. Mandisodza, Amir Goren and Crystal C. Hall. 2005. "Inferences of Competence from Faces Predict Election Outcomes." Science 308(5728):1623-1626.

URL: http://www.sciencemag.org/cgi/doi/10.1126/science.1110589

Weisbrod, Burton. 2004. "The pitfalls of profits." Stanford Social Innovation Review 2(3):4047.

Weisbrod, Burton A. 1997. "The future of the nonprofit sector: Its entwining with private enterprise and government." Journal of Policy Analysis and Management 16(4):541-555.

URL: http://www.jstor.org/stable/3325926

Williams, Keelah EG, Oliver Sng and Steven L Neuberg. 2016. "Ecology-driven stereotypes override race stereotypes." Proceedings of the National Academy of Sciences 113(2):310315.

$\mathrm{Xu}$, Chengxin. 2020. "The Perceived Differences: The Sector Stereotype of Social Service Providers." Nonprofit and Voluntary Sector Quarterly pp. 1-18. 


\section{Appendix}

\section{Appendix A Sample Characteristics and Balance Test}

Table A.1: Study 1: Participant Characteristics and Balance Test

\begin{tabular}{|c|c|c|c|c|c|}
\hline & \multicolumn{5}{|c|}{ Experimental Conditions } \\
\hline & $\begin{array}{c}\text { Donation } \\
\%\end{array}$ & $\begin{array}{c}\text { Service Fees } \\
\%\end{array}$ & $\begin{array}{c}\text { Government Fund } \\
\%\end{array}$ & $\begin{array}{c}\text { Total } \\
\%\end{array}$ & $\chi^{2} p$ \\
\hline Gender & & & & & .458 \\
\hline Female & 81.0 & 84.6 & 82.6 & 82.8 & \\
\hline Male & 19.0 & 15.4 & 17.4 & 17.2 & \\
\hline Total & 100.0 & 100.0 & 100.0 & 100.0 & \\
\hline Age & & & & & 0.808 \\
\hline 19 or under & 2.2 & 2.6 & 3.1 & 2.7 & \\
\hline $20-29$ & 26.8 & 29.6 & 30.1 & 28.9 & \\
\hline $30-39$ & 30.8 & 27.8 & 27.3 & 28.5 & \\
\hline $40-49$ & 19.0 & 19.7 & 15.1 & 17.8 & \\
\hline $50-59$ & 11.2 & 11.9 & 12.2 & 11.8 & \\
\hline $60-69$ & 6.2 & 5.2 & 8.1 & 6.6 & \\
\hline 70 or older & 3.7 & 3.2 & 4.2 & 3.7 & \\
\hline Total & 100.0 & 100.0 & 100.0 & 100.0 & \\
\hline Race & & & & & .848 \\
\hline White & 72.8 & 73.3 & 71.4 & 72.4 & \\
\hline Black & 10.3 & 10.5 & 12.2 & 11.1 & \\
\hline Hispanic & 9.7 & 7.6 & 9.4 & 8.9 & \\
\hline Asian & 4.4 & 4.9 & 3.1 & 4.1 & \\
\hline Other & 2.8 & 3.8 & 3.9 & 3.5 & \\
\hline Education & & & & & .592 \\
\hline Less than high school & 3.1 & 3.5 & 4.4 & 3.7 & \\
\hline High school/GED & 28.7 & 22.9 & 23.9 & 25.0 & \\
\hline Some college & 26.6 & 33.3 & 26.0 & 28.6 & \\
\hline 2-year college degree & 13.8 & 12.5 & 16.4 & 14.3 & \\
\hline 4-year college degree & 18.8 & 16.8 & 19.7 & 18.5 & \\
\hline Master degree & 6.3 & 6.7 & 5.7 & 6.2 & \\
\hline Doctor Degree & 0.6 & 0.9 & 1.0 & 0.9 & \\
\hline Professional degree & 1.9 & 2.6 & 1.6 & 2.0 & \\
\hline Other & 0.3 & 0.9 & 1.3 & 0.9 & \\
\hline Total & 100.0 & 100.0 & 100.0 & 100.0 & \\
\hline Income & & & & & .849 \\
\hline Less than $\$ 25,000$ & 24.6 & 25.6 & 28.4 & 26.3 & \\
\hline$\$ 25,000$ to $\$ 34,999$ & 19.6 & 18.0 & 19.0 & 18.9 & \\
\hline$\$ 35,000$ to $\$ 49,999$ & 16.8 & 14.8 & 14.8 & 15.4 & \\
\hline$\$ 50,000$ to $\$ 74,999$ & 19.3 & 18.6 & 20.6 & 19.5 & \\
\hline$\$ 75,000$ to $\$ 99,999$ & 9.3 & 12.8 & 8.1 & 10.0 & \\
\hline$\$ 100,000$ to $\$ 149,999$ & 8.7 & 8.1 & 7.3 & 8.0 & \\
\hline$\$ 150,000$ or more & 1.6 & 2.0 & 1.8 & 1.8 & \\
\hline Total & 100.0 & 100.0 & 100.0 & 100.0 & \\
\hline
\end{tabular}


Table A.2: Study 2: Participant Characteristics and Balance Test

\begin{tabular}{|c|c|c|c|c|c|}
\hline & \multicolumn{5}{|c|}{ Experimental Conditions } \\
\hline & $\begin{array}{c}\text { Donation } \\
\% \\
\end{array}$ & $\begin{array}{c}\text { Fee } \\
\%\end{array}$ & $\begin{array}{c}\text { Government fund } \\
\%\end{array}$ & $\begin{array}{c}\text { Total } \\
\%\end{array}$ & $\chi^{2} p$ \\
\hline Gender & & & & & .871 \\
\hline Male & 48.0 & 47.9 & 50.2 & 48.7 & \\
\hline Female & 52.0 & 52.1 & 49.8 & 51.3 & \\
\hline Total & 100.0 & 100.0 & 100.0 & 100.0 & \\
\hline Age & & & & & .050 \\
\hline 19 or under & 0.0 & 1.5 & 1.4 & 1.0 & \\
\hline $20-29$ & 24.6 & 32.0 & 22.6 & 26.3 & \\
\hline 30-39 & 34.8 & 22.5 & 36.5 & 31.4 & \\
\hline $40-49$ & 17.4 & 21.0 & 14.4 & 17.6 & \\
\hline $50-59$ & 11.6 & 11.5 & 13.5 & 12.2 & \\
\hline $60-69$ & 8.7 & 5.5 & 6.7 & 7.0 & \\
\hline 70 or older & 2.9 & 6.0 & 4.8 & 4.6 & \\
\hline Total & 100.0 & 100.0 & 100.0 & 100.0 & \\
\hline Race & & & & & .037 \\
\hline White & 70.0 & 79.5 & 64.7 & 71.2 & \\
\hline Black & 12.8 & 6.8 & 18.4 & 12.8 & \\
\hline Hispanic & 5.9 & 5.3 & 5.0 & 5.4 & \\
\hline Asian & 9.9 & 7.4 & 9.0 & 8.8 & \\
\hline Other & 1.5 & 1.1 & 3.0 & 1.9 & \\
\hline Total & 100.0 & 100.0 & 100.0 & 100.0 & \\
\hline Education & & & & & .446 \\
\hline Less than high school & 1.5 & 0.5 & 1.0 & 1.0 & \\
\hline High school/GED & 9.3 & 12.0 & 6.4 & 9.2 & \\
\hline Some college & 21.6 & 21.4 & 23.2 & 22.0 & \\
\hline 2-year college degree & 11.8 & 13.0 & 12.8 & 12.5 & \\
\hline 4-year college degree & 43.6 & 38.5 & 44.3 & 42.2 & \\
\hline Master degree & 8.8 & 13.5 & 10.3 & 10.9 & \\
\hline Doctor Degree & 2.5 & 0.0 & 2.0 & 1.5 & \\
\hline Professional degree & 1.0 & 1.0 & 0.0 & 0.7 & \\
\hline Total & 100.0 & 100.0 & 100.0 & 100.0 & \\
\hline Income & & & & & .097 \\
\hline Less than $\$ 25,000$ & 13.3 & 14.7 & 13.9 & 13.9 & \\
\hline$\$ 25,000$ to $\$ 34,999$ & 11.8 & 11.5 & 12.9 & 12.1 & \\
\hline$\$ 35,000$ to $\$ 49,999$ & 20.7 & 17.8 & 17.3 & 18.6 & \\
\hline$\$ 50,000$ to $\$ 74,999$ & 22.7 & 31.4 & 23.8 & 25.8 & \\
\hline$\$ 75,000$ to $\$ 99,999$ & 16.3 & 9.4 & 14.4 & 13.4 & \\
\hline$\$ 100,000$ to $\$ 149,999$ & 9.4 & 13.6 & 15.8 & 12.9 & \\
\hline$\$ 150,000$ or more & 5.9 & 1.6 & 2.0 & 3.2 & \\
\hline Total & 100.0 & 100.0 & 100.0 & 100.0 & \\
\hline
\end{tabular}




\section{Appendix B Results of Factor Analysis}

Table B.1: Study 1

\begin{tabular}{lccc}
\hline \hline & Factor 1 & Factor 2 & Cronbach's $\alpha$ \\
\hline Warmth & & & .9333 \\
Warm & .8140 & & \\
Kind & .8129 & & \\
Generous & .7167 & & .9311 \\
Competence & & & \\
Competent & & .7620 & \\
Effective & & .8059 & \\
Efficient & & .7905 & \\
\hline \hline
\end{tabular}

Note: Factor loads lower than .60 are omitted.

Table B.2: Study 2

\begin{tabular}{lccc}
\hline \hline & Factor 1 & Factor 2 & Cronbach's $\alpha$ \\
\hline Warmth & & & .9171 \\
Warm & .7672 & & \\
Kind & .7485 & & \\
Generous & .6957 & & .9327 \\
Competence & & & \\
Competent & & .7700 & \\
Effective & & .7455 & \\
Efficient & & .7611 & \\
\hline \hline
\end{tabular}

Note: Factor loads lower than .60 are omitted. 


\section{Appendix C Study 2: Experimental Vignettes}
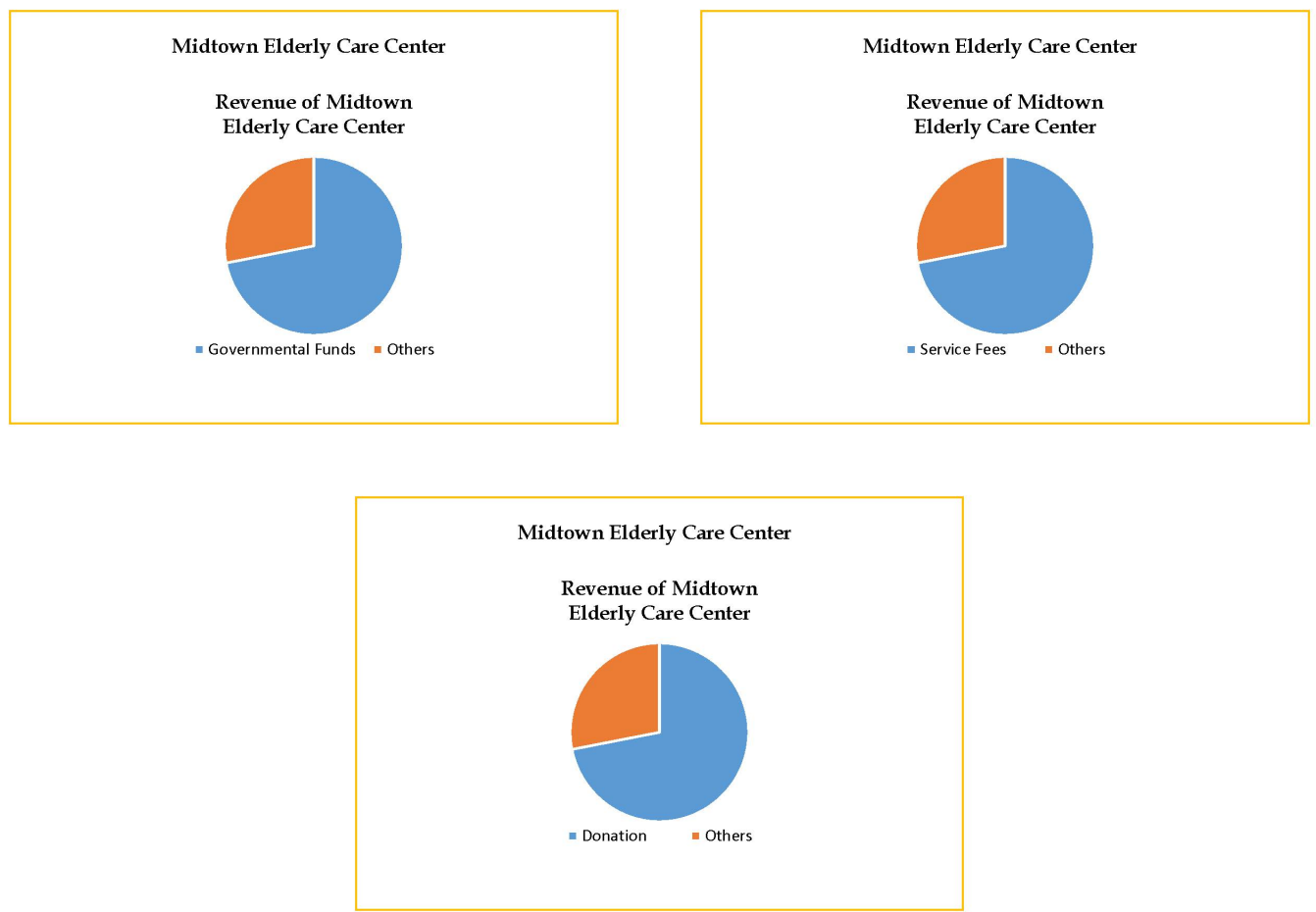


\section{Appendix D Regression Tables}

Table D.1: Study 1: OLS Regression Results

\begin{tabular}{|c|c|c|c|c|}
\hline & $\begin{array}{c}(1) \\
\text { Warmth }\end{array}$ & $\begin{array}{c}(2) \\
\text { Warmth }\end{array}$ & $\begin{array}{c}(3) \\
\text { Competence }\end{array}$ & $\begin{array}{c}(4) \\
\text { Competence }\end{array}$ \\
\hline Service Fee & $\begin{array}{c}-9.347^{* * *} \\
(1.825)\end{array}$ & $\begin{array}{c}-9.351^{* * *} \\
(1.825)\end{array}$ & $\begin{array}{c}-6.851^{* * *} \\
(1.780)\end{array}$ & $\begin{array}{c}-6.881^{* * *} \\
(1.780)\end{array}$ \\
\hline Government Funding & $\begin{array}{c}-5.627^{* *} \\
(1.778)\end{array}$ & $\begin{array}{c}-5.655^{* *} \\
(1.778)\end{array}$ & $\begin{array}{l}-3.251 \\
(1.734)\end{array}$ & $\begin{array}{l}-3.286 \\
(1.735)\end{array}$ \\
\hline Male & & $\begin{array}{c}2.240 \\
(1.949)\end{array}$ & & $\begin{array}{c}1.139 \\
(1.902)\end{array}$ \\
\hline Age & & $\begin{array}{l}-0.174 \\
(0.518)\end{array}$ & & $\begin{array}{l}0.0319 \\
(0.505)\end{array}$ \\
\hline Education & & $\begin{array}{c}0.594 \\
(0.493)\end{array}$ & & $\begin{array}{c}0.529 \\
(0.481)\end{array}$ \\
\hline Income & & $\begin{array}{c}0.224 \\
(0.470)\end{array}$ & & $\begin{array}{c}0.296 \\
(0.458)\end{array}$ \\
\hline White & & $\begin{array}{l}-3.298^{*} \\
(1.648)\end{array}$ & & $\begin{array}{l}-3.401^{*} \\
(1.608)\end{array}$ \\
\hline Constant & $\begin{array}{c}68.32^{* * *} \\
(1.309)\end{array}$ & $\begin{array}{c}68.13^{* * *} \\
(2.825)\end{array}$ & $\begin{array}{c}65.60^{* * *} \\
(1.277)\end{array}$ & $\begin{array}{c}65.00^{* * *} \\
(2.757)\end{array}$ \\
\hline$N$ & 1034 & 1034 & 1034 & 1034 \\
\hline$R^{2}$ & 0.025 & 0.033 & 0.014 & 0.021 \\
\hline $\operatorname{Adj} \cdot R^{2}$ & 0.023 & 0.026 & 0.012 & 0.014 \\
\hline
\end{tabular}

Standard errors in parentheses

${ }^{*} p<0.05,{ }^{* *} p<0.01,{ }^{* * *} p<0.001$ 
Table D.2: Study 1:OLS Regression Results for Gender Subgroups

\begin{tabular}{lcccc}
\hline \hline & \multicolumn{2}{c}{ Male } & \multicolumn{2}{c}{ Female } \\
& $(1)$ & $(2)$ & $(3)$ & $(4)$ \\
& Warmth & Competence & Warmth & Competence \\
\hline Service Fee & $-14.29^{* * *}$ & $-10.05^{*}$ & $-8.217^{* * *}$ & $-6.198^{* *}$ \\
& $(4.203)$ & $(4.290)$ & $(2.026)$ & $(1.960)$ \\
Government Funding & $-8.018^{*}$ & -1.257 & $-5.016^{*}$ & -3.642 \\
& $(3.955)$ & $(4.037)$ & $(1.987)$ & $(1.922)$ \\
Constant & & & & \\
& $72.57^{* * *}$ & $66.92^{* * *}$ & $67.31^{* * *}$ & $65.28^{* * *}$ \\
\hline$N$ & $(2.851)$ & $(2.910)$ & $(1.469)$ & $(1.421)$ \\
$R^{2}$ & 179 & 179 & 855 & 855 \\
adj. $R^{2}$ & 0.062 & 0.035 & 0.019 & 0.012 \\
\hline \hline
\end{tabular}

Standard errors in parentheses

${ }^{*} p<0.05,{ }^{* *} p<0.01,{ }^{* * *} p<0.001$ 
Table D.3: Study 2: OLS Regression Results

\begin{tabular}{|c|c|c|c|c|}
\hline & $\begin{array}{c}(1) \\
\text { Warmth }\end{array}$ & $\begin{array}{c}(2) \\
\text { Warmth }\end{array}$ & $\begin{array}{c}(3) \\
\text { Competence }\end{array}$ & $\begin{array}{c}(4) \\
\text { Competence }\end{array}$ \\
\hline Service Fee & $\begin{array}{c}-9.433^{* * *} \\
(2.804)\end{array}$ & $\begin{array}{c}-7.907^{* *} \\
(2.778)\end{array}$ & $\begin{array}{l}-4.991 \\
(2.839)\end{array}$ & $\begin{array}{l}-3.433 \\
(2.818)\end{array}$ \\
\hline Government Funding & $\begin{array}{c}-7.040^{* *} \\
(2.531)\end{array}$ & $\begin{array}{c}-6.660^{* *} \\
(2.494)\end{array}$ & $\begin{array}{l}-6.549^{*} \\
(2.562)\end{array}$ & $\begin{array}{l}-6.239^{*} \\
(2.530)\end{array}$ \\
\hline Prosocial Mission & $\begin{array}{l}-1.491 \\
(2.632)\end{array}$ & $\begin{array}{l}-0.874 \\
(2.606)\end{array}$ & $\begin{array}{l}-5.779^{*} \\
(2.665)\end{array}$ & $\begin{array}{l}-5.229^{*} \\
(2.644)\end{array}$ \\
\hline Prosocial $\times$ Service Fee & $\begin{array}{c}0.743 \\
(3.806)\end{array}$ & $\begin{array}{c}0.205 \\
(3.756)\end{array}$ & $\begin{array}{c}1.520 \\
(3.853)\end{array}$ & $\begin{array}{c}1.040 \\
(3.811)\end{array}$ \\
\hline Prosocial $\times$ Government Funding & $\begin{array}{c}4.315 \\
(3.761)\end{array}$ & $\begin{array}{c}4.373 \\
(3.694)\end{array}$ & $\begin{array}{l}8.591^{*} \\
(3.808)\end{array}$ & $\begin{array}{l}8.601^{*} \\
(3.748)\end{array}$ \\
\hline Donor Experience & & $\begin{array}{c}2.861^{* * *} \\
(0.683)\end{array}$ & & $\begin{array}{c}2.777^{* * *} \\
(0.693)\end{array}$ \\
\hline User Experience & & $\begin{array}{l}-1.124 \\
(1.601)\end{array}$ & & $\begin{array}{l}-0.845 \\
(1.624)\end{array}$ \\
\hline Male & & $\begin{array}{l}-1.006 \\
(1.550)\end{array}$ & & $\begin{array}{l}-0.725 \\
(1.572)\end{array}$ \\
\hline Age & & $\begin{array}{l}-0.0442 \\
(0.0590)\end{array}$ & & $\begin{array}{l}-0.0211 \\
(0.0599)\end{array}$ \\
\hline Education & & $\begin{array}{l}-1.466^{*} \\
(0.615)\end{array}$ & & $\begin{array}{l}-1.192 \\
(0.624)\end{array}$ \\
\hline Income & & $\begin{array}{l}-0.193 \\
(0.485)\end{array}$ & & $\begin{array}{l}-0.339 \\
(0.492)\end{array}$ \\
\hline White & & $\begin{array}{l}-4.327^{*} \\
(1.746)\end{array}$ & & $\begin{array}{c}-4.998^{* *} \\
(1.771)\end{array}$ \\
\hline Constant & $\begin{array}{c}26.40^{* * *} \\
(1.803)\end{array}$ & $\begin{array}{c}32.09^{* * *} \\
(4.873)\end{array}$ & $\begin{array}{c}27.93^{* * *} \\
(1.826)\end{array}$ & $\begin{array}{c}32.25^{* * *} \\
(4.944)\end{array}$ \\
\hline$N$ & 525 & 525 & 525 & 525 \\
\hline$R^{2}$ & 0.047 & 0.099 & 0.028 & 0.077 \\
\hline Adj. $R^{2}$ & 0.038 & 0.078 & 0.018 & 0.055 \\
\hline
\end{tabular}

Standard errors in parentheses

${ }^{*} p<0.05,{ }^{* *} p<0.01,{ }^{* * *} p<0.001$ 
Table D.4: Study 2: OLS Regression Results Cont.

\begin{tabular}{|c|c|c|c|c|}
\hline & (1) & $(2)$ & (3) & $(4)$ \\
\hline & Willingness to Donate & Willingness to Donate & Willingness to Purchase & Willingness to Purchase \\
\hline \multirow[t]{2}{*}{ Service Fee } & $-10.04^{*}$ & -6.409 & -3.851 & -3.894 \\
\hline & $(4.385)$ & $(4.198)$ & $(4.184)$ & $(4.230)$ \\
\hline \multirow[t]{2}{*}{ Government Funding } & -1.436 & -0.168 & -2.035 & -1.874 \\
\hline & $(3.958)$ & $(3.768)$ & $(3.776)$ & $(3.797)$ \\
\hline \multirow[t]{2}{*}{ Prosocial Mission } & 1.081 & 2.976 & -1.583 & -1.817 \\
\hline & $(4.117)$ & $(3.938)$ & $(3.928)$ & $(3.968)$ \\
\hline \multirow[t]{2}{*}{ Prosocial $\times$ Service Fee } & -5.394 & -6.944 & -0.578 & 0.157 \\
\hline & $(5.952)$ & $(5.675)$ & $(5.678)$ & $(5.718)$ \\
\hline \multirow[t]{2}{*}{ Prosocial $\times$ Government Funding } & -4.529 & -4.910 & -0.690 & -0.421 \\
\hline & $(5.882)$ & $(5.582)$ & $(5.612)$ & $(5.624)$ \\
\hline \multirow[t]{2}{*}{ Donor Experience } & & $7.505^{* * *}$ & & $2.268^{*}$ \\
\hline & & $(1.032)$ & & $(1.040)$ \\
\hline \multirow[t]{2}{*}{ User Experience } & & -2.865 & & -3.440 \\
\hline & & $(2.419)$ & & $(2.437)$ \\
\hline \multirow[t]{2}{*}{ Male } & & -2.383 & & 3.091 \\
\hline & & $(2.342)$ & & $(2.359)$ \\
\hline \multirow[t]{2}{*}{ Age } & & -0.102 & & -0.0454 \\
\hline & & $(0.0892)$ & & $(0.0899)$ \\
\hline \multirow[t]{2}{*}{ Education } & & -1.719 & & -0.415 \\
\hline & & $(0.929)$ & & $(0.936)$ \\
\hline \multirow[t]{2}{*}{ Income } & & -0.872 & & -0.203 \\
\hline & & $(0.733)$ & & $(0.738)$ \\
\hline \multirow[t]{2}{*}{ White } & & $-7.133^{* *}$ & & 0.659 \\
\hline & & $(2.638)$ & & (2.658) \\
\hline \multirow[t]{2}{*}{ Constant } & $12.25^{* * *}$ & $15.56^{*}$ & $13.82^{* * *}$ & $15.66^{*}$ \\
\hline & $(2.820)$ & $(7.363)$ & $(2.691)$ & $(7.420)$ \\
\hline$N$ & 525 & 525 & 525 & 525 \\
\hline$R^{2}$ & 0.043 & 0.156 & 0.006 & 0.022 \\
\hline Adj. $R^{2}$ & 0.034 & 0.136 & -0.003 & -0.001 \\
\hline
\end{tabular}

Standard errors in parentheses

${ }^{*} p<0.05,{ }^{* *} p<0.01,{ }^{* * *} p<0.001$ 